\title{
The changing abundance and distribution of Greater White-fronted Geese Anser albifrons in the Yangtze River floodplain: impacts of recent hydrological changes
}

\author{
MEIJUAN ZHAO, PEIHAO CONG, MARK BARTER, ANTHONY D. FOX and \\ LEI CAO
}

\begin{abstract}
Summary
Count data show that wintering Greater White-fronted Goose Anser albifrons numbers in their Chinese stronghold (the Yangtze River catchment) have fallen from about 140,00o in the late 1980 and early 1990 s to c.18,000 now, despite increases in the overall flyway population (mostly wintering in South Korea and Japan). Declines have occurred in Jiangxi, but most markedly in Hunan (predominantly at East Dongting Lake) where the decline has been steady since 2003/2004, with few left from 2008/2009 onwards. Numbers have increased substantially in Anhui (predominantly at Shengjin Lake), which now supports more Greater White-fronted Geese than Jiangxi and Hunan combined. The species appears a habitat specialist in China, confined to grazing shortsward recessional Carex sedge meadows. At East Dongting Lake, reductions in Greater Whitefronted Geese numbers correlated with declines in availability of suitable sedge swards, caused by earlier water table recession, which in recent years has meant swards were too tall for geese to utilise from their arrival in autumn. The hydrological changes are most probably due to the commissioning of the Three Gorges Dam in mid-2003. At Shengjin Lake, the increases may be due to recent stable first exposure dates and slow water recession rates which favour short Carex swards attractive to geese; high buffalo grazing density at this lake may also assist in maintaining suitable sward heights. These hypotheses require investigation.
\end{abstract}

\section{Introduction}

The East Asian population of the Greater White-fronted Goose Anser albifrons was thought to number around 130,000 individuals, 33,000 in eastern China in the mid-2000s plus 30,000 in South Korea and 70,000 in Japan, based on mid-winter average counts from 2000-2004 (Cao et al. 2008). However, recent information suggests greatly increased numbers in South Korea and Japan (H. Lee unpubl. data; Asian Waterbird Census unpubl. data), although not in China, so the East Asian population could currently exceed 250,000.

In Japan and South Korea, as in Europe, Greater White-fronted Geese forage in agricultural habitats, mainly on spilt rice, winter wheat and improved pastures (Kear 2005, Madsen et al. 1999, Shimada 2002, Syroechkovskiy 2006). Those wintering in the North American Pacific Flyway (the same subspecies as Chinese wintering birds) forage on a variety of cereals, potatoes, and agricultural and wild grasses (Ely and Raveling 2011). In contrast, in eastern China, the species feeds primarily on Carex spp. (Zhang and Lu 1999, Cheng et al. 2009) in natural wetlands that are seriously threatened by hydrological changes caused by the construction of thousands of 
water control structures, and particularly exacerbated by the commissioning of the Three Gorges Dam in 2003, the largest in the world (Xu et al. 2006, Yang et al. 2006, Yang et al. 2007).

Given the small Chinese wintering population and its narrow food preference that depends on the annual natural floodplain flood-drought cycle, it is important to understand the impacts of changes in floodplain hydrology on food availability, goose numbers and distribution. The Carex sedges favoured by Greater White-fronted Geese grow rapidly in autumn as they are exposed by water table recession in the Yangtze River wetlands. Geese generally exploit short swards of graminoid plants which are highest in protein and lowest in structural carbohydrates with initial onset of growth (e.g. Cadieux et al. 2005), so it is important that geese start to exploit these plants during the period when they reach optimal quality and lamina length. Increased protein content of leaves is a common response of monocotyledonous plants to grazing (Ydenberg and Prins 1981, Cargill and Jefferies 1984, Fox and Kahlert 2003), so if geese arrive to optimal sward length, repeated grazing can maintain the sward in a suitable condition for sustained foraging. Once sedges grow too tall, they are abandoned by geese (authors' unpubl. data). Hence, the dates at which sedge beds are first exposed by receding water levels, and thus the extent of sedge of suitable sward length that is available, are likely to determine the number of geese a site can sustain during the winter. Since water levels within the Yangtze River floodplain are now greatly modified and levels recede as the dam is refilled in early autumn (following lowering to absorb the summer monsoonal floods) (Wang et al. 2005), this could be a crucial factor affecting numbers of Greater White-fronted Geese using a site.

Some of our earlier work, particularly on the impact of changing hydrological regimes on submerged macrophytes within the floodplain, provided strong indications that these changes led to greatly reduced waterbird food production (Cao et al. $2011 \mathrm{~b}$, Meng et al. in prep.), with a negative impact on waterbird numbers (Cao 2011, Cong et al. 2011, Fox et al. 2010, Zhang et al. 2011. However, many waterbirds graze on sedges and it is important to establish whether sedge availability, and the species which depend on them, are also affected by the recent dramatic changes in Yangtze floodplain hydrology.

In this paper, we report historical and contemporary information on the abundance and distribution of wintering Greater White-fronted Geese in east China and test the hypothesis that the recent decline in numbers at East Dongting Lake, a previously important site for Greater White-fronted Geese, is due to recent large changes in floodplain hydrology affecting their traditional sedge food supply.

\section{Methods}

\section{Study area}

The Yangtze River floodplain, stretching for $1,850 \mathrm{~km}$ from the Three Gorges Dam (TGD), through Hubei, Hunan, Jiangxi, Anhui and Jiangsu provinces to the estuary at Shanghai (Figure 1 ), is subjected to large annual variation in water levels between the summer flood and winter dry seasons (Shankman and Liang 2003), creating numerous, shallow, ephemeral and highly productive wetlands with an area of approximately $10,500 \mathrm{~km}^{2}$ (He and Zhang 2001).

Dongting Lake $\left(4,350 \mathrm{~km}^{2}\right)$, the second largest lake in the floodplain after Poyang Lake $\left(5,100 \mathrm{~km}^{2}\right)$, is located about $450 \mathrm{~km}$ downstream of the Three Gorges Dam (TGD); both lakes are linked directly to the Yangtze River, filling by sheet flow during the flood season. Dongting Lake has historically been used as the major means of flood control and sediment retention in the middle reaches of the Yangtze River, but this purpose has been greatly reduced since the commissioning of the TGD in mid-2003 (Dai et al. 2005, Wang et al. 2005). Water levels in numerous smaller lakes in Hubei and Anhui Provinces are controlled by sluices to allow water to enter from the Yangtze River and to exit following precipitation within the lake catchment; sluices are generally closed during May-September, to minimise flooding in the rainy season, and opened October-April, to allow water to drain into the Yangtze River to lower levels to facilitate fishing and avoid spring flooding.

Average annual rainfall across the key Greater White-fronted Geese provinces ranges from 1,361 to $1,623 \mathrm{~mm}$ (average of 1,459 mm from Anqing, Nanchang and Yueyang); most falls from 


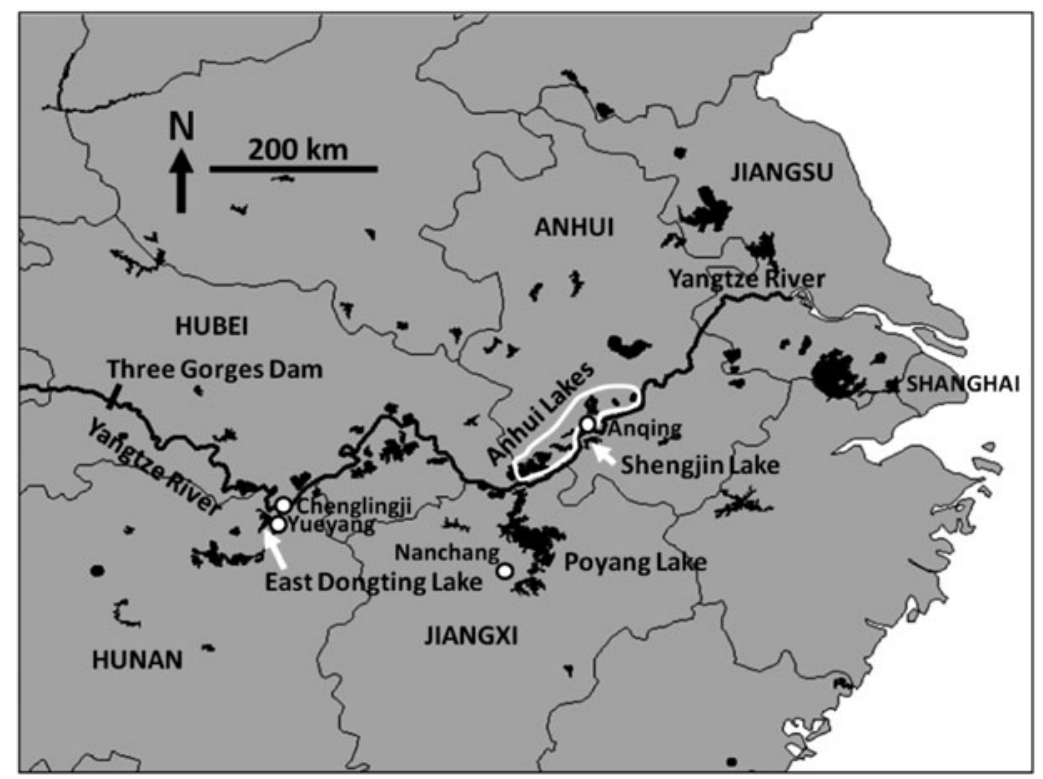

Figure 1. Yangtze River floodplain from the Three Gorges Dam to the river estuary at Shanghai, showing locations of provinces, wetlands and places mentioned in the text.

March to August. Annual average temperature is $18.0^{\circ} \mathrm{C}$ (range $17.6-18.4^{\circ} \mathrm{C}$ ); average January temperature is $5 \cdot 1^{\circ} \mathrm{C}$ (range $4 \cdot 4-5 \cdot 7^{\circ} \mathrm{C}$ ).

\section{Goose abundance and distribution data}

Early count data during 1987-1999 are incomplete (Table 1) and to facilitate analysis, maximum annual site counts have been used; data were organised into two six-year periods: 1987/19881992/1993 and 1993/1994-1998/1999.

In February of 2004 and 2005, the first comprehensive, synchronous waterbird surveys were conducted throughout the Yangtze River floodplain (Barter et al. 2004, 2006), enabling comparison of numbers and distribution to be made with more recent counts.

Key sites within East Dongting Lake were counted every month in winters 2008/2009 (FebruaryApril) and 2009/2010 (October-April; L. Cao unpubl. data). Frequent winter counts were conducted at Shengjin Lake (Anhui Province), nine times in 2008/2009 (Cheng et al. 2009), and 13 times in 2009/2010 (Meng 2010); we also surveyed all the main Anhui Lakes twice during the 2009/2010 winter (L. Cao unpubl. data).

Counts from key floodplain wetlands in winters 2005/06-2008/o9 were also available, mainly from unpublished nature reserve monitoring data. Synchronous counts were made at Dongting Lake, Poyang Lake and Chongming Island (Yangtze River estuary) but those from the Anhui Lakes were mostly collected opportunistically and occurred at different periods within and between winters. Interpretation of these non-systematic data provides useful additional information on key sites for Greater White-fronted Goose.

\section{Carex availability at East Dongting Lake}

Preliminary analysis suggested that Greater White-fronted Goose numbers had declined at East Dongting Lake, so for the years 1998-2010, we modelled changes in availability of Carex 
Table 1. Greater White-fronted Goose numbers during the 1987/1988-2009/10 winters in the Yangtze River floodplain provinces.

\begin{tabular}{|c|c|c|c|c|c|c|c|}
\hline Winter & Anhui & Jiangxi & Hunan & Hubei & Jiangsu & Shanghai & Total \\
\hline $1987 / 88-1992 / 93$ & $2,100^{\mathrm{a}}$ & $86,900^{b}$ & $50,013^{a}$ & $255^{\mathrm{a}}$ & $1,097^{b}$ & $\mathrm{O}$ & 140,365 \\
\hline $1993 / 94-1998 / 99$ & $5,013^{\mathrm{a}}$ & $86,500^{b}$ & $50,000^{c}$ & $450^{d}$ & $196^{\mathrm{b}}$ & o & 142,159 \\
\hline $2003 / 2004$ & 97 & 12,568 & 12,576 & $\mathrm{O}$ & - & o & 25,241 \\
\hline $2004 / 2005$ & 47 & 15,602 & 9,495 & $1,35^{\circ}$ & o & o & 26,494 \\
\hline $2005 / 2006$ & $0^{1}$ & $56,438^{6}$ & $3,274^{11}$ & - & - & $14^{17}$ & 59,726 \\
\hline $2006 / 2007$ & $1^{2}$ & $22,368^{7}$ & $3,291^{12}$ & - & - & - & 25,660 \\
\hline $2007 / 2008$ & $5,518^{3}$ & $41,773^{8}$ & $4,645^{13}$ & $578^{16}$ & - & $0^{18}$ & 47,291 \\
\hline $2008 / 2009$ & $7,021^{4}$ & $10,312^{9}$ & $619^{14}$ & - & - & $\mathbf{0}^{19}$ & $17,95^{2}$ \\
\hline $2009 / 2010$ & $11,217^{5}$ & $6,790^{10}$ & $78^{15}$ & - & - & - & 18,085 \\
\hline
\end{tabular}

Notes: 2003/2004, 2004/2005 and 2009/2010 counts conducted in early February; italics identify incomplete counts (numbers were probably higher); "-"indicates no data available. a: Waterbird Specialist Group of Chinese Ornithological Association (1994); b: D. Lee (in litt.); c: Lei and Yang (1999); d: Ge et al. (2005). 1-4: unpubl. data from the Anhui Lakes $(1=$ mid-March; 2 = December-January; 3 = January-February; 4 = December-March); 5: February count (L. Cao unpubl. data); 6-9: unpubl. data from GEF Siberian Crane Project (6-8 = late December-early January; $9=13$ February 2009); 10: unpubl. data from "Impact of Poyang Lake Dam on wetlands and waterbirds" project (count on 27 Feb. 2010); 11-14: unpubl. data from Dongting Lake (February counts); 15: February count for core areas of East Dongting Lake and Caisang Lake within East Dongting Lake, which has normally held 70-85\% of Greater White-fronted Geese in Hunan in the past (L. Cao unpubl. data); 16: February count; Hu et al. 2008; 17-19: unpubl. data from Chongming Dongtan National Bird Nature Reserve, most important site in Shanghai (February counts).

heterolepis (the dominant Carex species at the lake) during the period that geese arrived following southward migration.

We first estimated the annual total meadow area by summing the areas of the three separate Carex-dominated Greater White-fronted Goose foraging sites (those from which count data were also available). For two of the sites (Chung Feng Lake and The Corner) we used shapefiles drawn with ArcMap 9.3 (ESRI Inc., Redlands, CA, USA) on Landsat ETM+ images (EROS 2010), whilst direct measurement of the main goose meadow area (Central Management Station) was derived from a GPS track generated by walking around the Carex meadow border.

We then assessed the annual proportion of this area which was suitable for grazing by geese on their arrival from the breeding grounds. Studies of grazing preferences showed that arriving Greater White-fronted Geese fed on graminoid swards 1-8 cm high (Owen 1972), so we excluded areas with Carex swards above $8 \mathrm{~cm}$ as being too tall for geese to exploit for feeding. We selected 25 October as the average arrival date because main arrivals of Greater White-fronted Geese at Shengjin Lake occurred during the last 1o days of October in 2008, 2009 and 2010 (Cheng et al. 2009, Meng 2010, L. Cao unpubl. data).

C. heterolepis leaf growth rates were measured twice per month at East Dongting Lake, from mid-October 2010 to early February 2011, on 50 tagged individual plants in two exclosed quadrats $(1 \mathrm{~m} \times 1 \mathrm{~m})$. Central leaves were measured from the leaf tip to the tip of the tagged leaf sheath every fortnight. Tagged Carex plants were replaced by new individuals if the original died or the tag was lost or destroyed.

We estimated the Carex growth rate to average $5.4 \mathrm{~mm} \mathrm{~d}^{-1}$ in the second half of October (see below and Figure 2). Thus, areas of Carex plants exposed on 1o October (i.e. 15 days earlier than the estimated 25 October arrival date) would be at the maximum length for successful exploitation (i.e. leaf length would be $5.4 \mathrm{~mm} \times 15 \mathrm{~d} \approx 80 \mathrm{~mm}$ ). On this basis, we calculated the total area of each of the three Carex meadows that was available in each year to arriving geese based on timing and pattern of exposure derived from satellite imagery.

In calculating the percentage of available area as a function of total area, we assumed that meadows were exposed at a uniform rate between initial and final exposure water levels (dates 


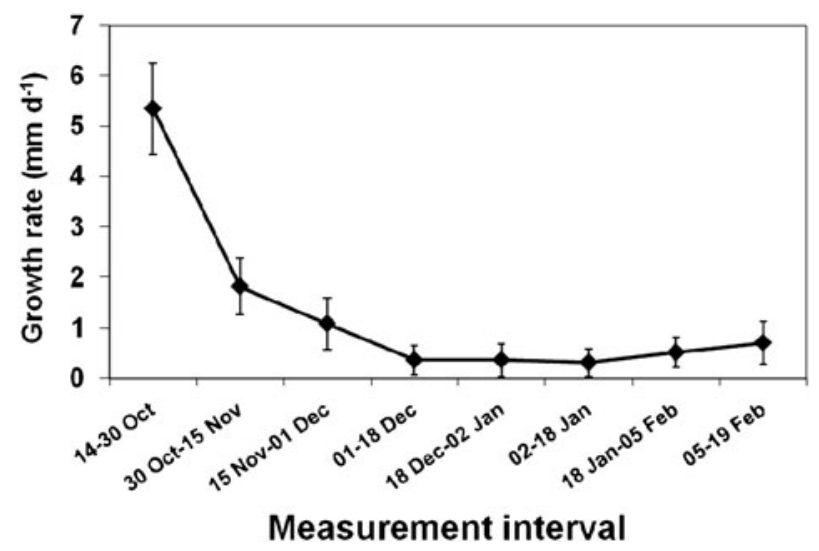

Figure 2. Average growth rate of Carex heterolepis at East Dongting Lake over approximately half-month periods, commencing in mid-October 2010.

determined from Chenglingji water levels, Huang Hai datum; obtained from Yangtze Water Resources Commission; initial and final exposure levels for each of the three foraging sites was determined from a series of satellite images taken at different water levels [Chung Feng Lake: 26.0-28.o m; Management Station: 25.0-27.5 m and The Corner: 25.5-26.5 m]). The percentage available area (A) was calculated from the number of days between 10 October and final exposure date (d) and the number of days between initial and final exposure dates (n) thus:

$$
A=(100 \times d) / n
$$

We then regressed the number of Greater White-fronted Geese (dependent variable) counted in January or February from 1999-2010 against the estimated suitable Carex area in the previous October to test our prediction that in years with reduced areas of suitable Carex availability, goose numbers would also be lower.

\section{Results}

\section{Historical and recent changes in abundance and distribution}

Although count data for 1987/88-1992/93 and 1993/1994-1998/1999 are variable, it is evident that Greater White-fronted Geese were more abundant in both these periods than subsequently, with the maximum numbers in Jiangxi and Hunan (which held the greatest numbers) alone each greatly exceeding current total numbers (Table 1 ). Even allowing for goose movements during winter, it is apparent that total numbers have declined from $>140,000$ to c.18,000 currently (Table 1). Declines have occurred in Jiangxi, but most markedly in Hunan (predominantly at East Dongting Lake (the most important site) where the decline has been steady since 2003/2004, with very few left from 2008/2009 onwards. Numbers have increased from very few to over 10,000 in Anhui (predominantly at Shengjin Lake) over the same time period, which now supports more Greater White-fronted Geese than Jiangxi and Hunan combined (Table 1).

\section{C. heterolepis growth rate}

The Carex growth rate declined from an average of $5.4 \mathrm{~mm} \mathrm{~d}^{-1}$ in the second half of October to less than $1 \mathrm{~mm} \mathrm{~d}^{-1}$ in mid-winter (Figure 2). We chose $5.4 \mathrm{~mm} \mathrm{~d}^{-1}$ as the growth rate during the 
period prior to geese arrival in late October, as the appropriate growth period to maximum exploitable length (10-25 October) is very similar to the field measurement period (14-30 October).

\section{Carex availability and goose numbers}

The total annual areas of suitable Carex, although variable, generally declined during the 19982010 period, as also did the number of Greater White-fronted Geese (Table 2). The annual extent (i.e. exposed area) of suitable Carex was a statistically significant predictor of the annual numbers of geese using the site $\left(r=0.65, F_{1,8}=5.81, P=0.04\right)$.

\section{Discussion}

Counts indicate that Greater White-fronted Goose numbers may have declined by as much as 90\% in eastern China since the 1990s. The causes remain unknown but could be linked to a combination of factors, including habitat loss and degradation in the Yangtze River floodplain (Lu and Zhang 1996, NWCAPC 2000, He and Zhang 2001), hunting (Lu 1993) and the specialised feeding ecology of the species. Short stopping may also have contributed, as global warming could have enabled birds to remain in previously less hospitable wintering areas, e.g. in South Korea where the availability of agricultural habitats and provision of refuges has extended the potential feeding and roosting areas (Syroechkovskiy 2006, authors' pers. obs.). Within China, recent count data show that Shengjin Lake is now the most important site for Greater White-fronts, with East Dongting Lake holding many fewer birds than previously.

The productivity of the Yangtze River floodplain wetlands is dependent on the summer monsoonal pulse of water, laden with nutrients, followed by the autumn-winter water recession which exposes rich feeding areas for many waterbirds. It has been suggested that flooding explains $50 \%$ of the variation in wetland communities, with nutrient supply explaining a further $15 \%$ (Keddy 2010); both these factors are very important at East Dongting Lake, which is located just $450 \mathrm{~km}$ downstream of the TGD and fills by sheet flow during the summer floods.

The available area of Carex upon arrival of the geese has been very small in four of the most recent years (Table 2), whereas it was abundant in earlier years. We believe this change is due to

Table 2. Annual availability of suitable Carex heterolepis (i.e. $\leq 8 \mathrm{~cm}$ upon geese arrival on 25 October) at the three main Greater White-fronted Goose foraging sites at East Dongting Lake (CMS = Central Management Station), total available area and goose counts ("-" = no data) in January-February.

\begin{tabular}{|c|c|c|c|c|c|c|c|c|}
\hline \multirow[t]{2}{*}{ Year } & \multicolumn{2}{|c|}{ Chung Feng Lake } & \multicolumn{2}{|l|}{ CMS } & \multicolumn{2}{|c|}{ The Corner } & \multirow{2}{*}{$\begin{array}{l}\text { Total area } \\
\text { available (ha) }\end{array}$} & \multirow{2}{*}{$\begin{array}{l}\text { Total } \\
\text { count }\end{array}$} \\
\hline & Area (ha) & $\%$ available & $\begin{array}{l}\text { Area } \\
\text { (ha) }\end{array}$ & $\%$ available & $\begin{array}{l}\text { Area } \\
\text { (ha) }\end{array}$ & $\%$ available & & \\
\hline 1999 & 259 & 85 & 68 & 100 & 126 & 100 & 414 & 8,000 \\
\hline 2000 & 259 & 100 & 68 & 100 & 126 & 100 & 453 & - \\
\hline 2001 & 259 & 100 & 68 & 100 & 126 & 100 & 453 & - \\
\hline 2002 & 259 & $\mathrm{o}$ & 68 & o & 126 & o & o & 4,417 \\
\hline 2003 & 259 & 77 & 68 & 100 & 126 & 100 & 393 & 12,576 \\
\hline 2004 & 259 & 42 & 68 & 64 & 126 & 100 & 279 & 9,495 \\
\hline 2005 & 259 & 40 & 68 & 100 & 126 & 100 & 298 & 3,274 \\
\hline 2006 & 259 & $\mathrm{o}$ & 68 & $\mathrm{o}$ & 126 & o & $\mathrm{o}$ & 3,291 \\
\hline 2007 & 259 & $\mathrm{o}$ & 68 & 46 & 126 & o & 31 & 4,645 \\
\hline 2008 & 259 & 30 & 68 & 63 & 126 & 100 & 246 & 619 \\
\hline 2009 & 259 & o & 68 & o & 126 & o & o & 78 \\
\hline 2010 & 259 & o & 68 & 76 & 126 & o & 52 & 1,442 \\
\hline
\end{tabular}


the commencement of refilling of the Three Gorges Dam in September each year, after lowering of the water level in the spring-summer period to accommodate flood water during the monsoon season. Therefore, it is likely that the hydrological changes wrought by the dam have contributed to impacts on waterbird food supplies. This is supported by observations that show falling numbers of Greater White-fronted Geese correlate with reductions in the area of suitable Carex meadow, mainly the result of earlier exposure of these beds in recent years, which has resulted in swards too high on goose arrival to permit their exploitation.

Greater White-fronted Geese have increased in number at Shengjin Lake, indicating more suitable conditions there in recent years. Hydrological changes at this sluice-controlled lake have caused the first exposure of the Carex meadow there to vary from 7 to 11 October during 20072010 (i.e. maximising the area of Carex of suitable grazing length), whereas in the previous six years first exposure dates varied greatly from 27 September to 15 October (unpubl. data). Hence, the more predictable availability of Carex in recent years may have supported the rapid increase in Greater White-fronted Geese numbers since 2006/2007. The rate of drawdown has also slowed (perhaps due to changes in sluice operation), maintaining wet conditions on the meadow for 52-62 days in 2008-2010 compared to 9-15 days in 2001-2005, a factor potentially contributing to maintaining the suitability of the sward for geese. The Shengjin Lake Carex meadows are also grazed intensively by up to 1,100 buffalo, which may also contribute to maintaining optimal sward length for the geese (Cao et al. 2011a). However, the causes and effects of hydrological change and buffalo grazing pressure on the vegetation require further investigation to provide a scientific basis for optimal management of water levels and buffalo numbers in order to maintain Greater White-fronted Goose numbers within the Shengjin Lake National Nature Reserve.

\section{Acknowledgements}

Special thanks go to Xin Wang for preparing the database of historical count data. The study was supported by National Basic Research Program of China (973 Program, Grant No. 2012CB956104), Chinese Academy of Sciences Innovation Project (Grant No. KZCX2-YW-QN503), Fundamental Research Funds for the Central Universities (Grant No. WK2060190007), plus a Chinese Academy of Sciences Visiting Professorship for Senior International Scientists (2011T1Zo4), State Administration of Foreign Experts Affairs, PRC.

\section{References}

Barter, M., Chen, L., Cao, L. and Lei, G. (2004) Waterbird survey of the middle and lower Yangtze river floodplain in late January and early February 2004. Beijing, China: China Forestry Publishing House.

Barter, M., Lei, G. and Cao, L. (2006) Waterbird survey of the middle and lower Yangtze river floodplain (February 2005). Beijing, China: China Forestry Publishing House.

Cadieux, M.-C., Gauthier, G. and Hughes, R. J. (2005) Feeding ecology of Canada Geese (Branta canadensis interior) in sub-arctic inland tundra during brood rearing. Auk 122: 144-157.

Cao, L., Barter, M. and Lei, G. (2008) New Anatidae population estimates for eastern
China: implications for current flyway estimates. Biol. Conserv. 141: 2301-2309.

Cao, L. (2011) Recent changes in wintering waterbirds at the key wetlands in the Yangtze River Floodplain, China. Pp. 110-122 in: J. Chen, ed. Environmental flows research and practice in China. Beijing, China: China Hydropower Publishing Company.

Cao, L., Barter, M., Zhao, M. J., Meng, H. X. and Zhang, Y. (2011a) A systematic scheme for monitoring waterbird populations at Shengjin Lake, China: methodology and preliminary results. Chi. Birds 2: 1-17.

Cao, L., Meng, F., Yang, W., Shan, K., Liu, J. and Fox, A. D. (2011b) Effects of length of growing season on biomass accumulation and reproductive investment of Vallisneria 
natans (Lour.) H. Hara seedlings. Fundam. Appl. Limnol. 179: 115-120.

Cargill, S. M. and Jefferies, R. L. (1984) The effects of grazing by Lesser Snow Geese on the vegetation of a sub-Arctic salt marsh. J. Appl. Ecol. 21: 669-686.

Cheng, Y. Q., Cao, L., Barter, M., Xu, W. B., Zhang, Y. and Zhao, M. J. (2009) Wintering waterbird survey at the Anhui Shengiin Lake National Nature Reserve, China 2008/9. Hefei, China: University of Science and Technology of China Press.

Cong, P. H., Cao, L., Fox, A. D., Barter, M., Reece, E. C., Chen, J., Jiang, Y., Ji, W. T., Zhu, W. Z. and Song, G. X. (2011) Recent changes in the distribution and abundance of Tundra Swans Cygnus columbianus bewickii in the Yangtze River floodplain. Bird Conserv. Int. DOI:10.1017/ So959270911000098.

Dai, S. B., Yang, S. L., Zhu, J., Gao, A. and Li, P. (2005) The role of Lake Dongting in regulating the sediment budget of the Yangtze River. Hydrol. Earth Syst. Sci. 9: 692-698.

Ely, C. R. and Raveling, D. G. (2011) Seasonal variation in nutritional characteristics of the diet of Greater White-fronted Geese. J. Wildl. Manage. 75: 78-91.

EROS (2010) US global visualisation viewer. Available at http://glovis.usgs.gov/.

Fox, A. D. and Kahlert, J. (2003) Repeated grazing of a salt marsh grass by moulting greylag geese Anser anser - does sequential harvesting optimise biomass or protein gain? J. Avian Biol. 34: 89-96.

Fox, A. D., Cao, L., Zhang, Y., Barter, M. Zhao, M. J., Meng, F. J. and Wang, S. L. (2010) Declines in the tuber-feeding waterbird guild at Shengjin Lake National Nature Reserve - a barometer of submerged macrophyte collapse. Aquat. Conserv.: Mar. Freshw. Ecosyst. 21: 82-91.

Ge, J. W., Cai, Q. H., Hu, H. X., Liu, J. K., Cao, G. B. and Liu, S. X. (2005) On species diversity and population size of rare, endangered and national key protected waterfowls in Hubei Province, China. Resour. Environ. Yangtze Basin 14: 50-54. (In Chinese).

He, Y. and Zhang, M. X. (2001) Study on wetland loss and its reasons in China. Chi. Geog. Sci. 11: 241-245.
Hu, H. X., Liu, Q. L., Tian, Y. P., Luo, S., Li, R. S. and Chen, X. (2008) Effect of snow disaster of 2008 on wetland waterbirds in Hubei - China. Crane News 12: 50-52.

Kear, J., ed. (2005) Ducks, geese and swans. Vol. I. New York: Oxford University Press.

Keddy, P. A. (2010) Wetland ecology: principles and conservation. $2^{\text {nd }}$ Edition. New York: Cambridge University Press.

Lei, G. and Yang, Y. Q. (1999) Summary report on wintering migrants in East Dongting Lake, 1998. Wetlands International China Programme Newsletter 2: 18.

Lu, J. J. (1993) The utilisation of migratory waterfowl in China. Pp. 90-92 in M. Moser and C. Prentice, eds. Waterfowl and wetlands conservation in the 1990s: a global perspective. Slimbridge, UK: IWRB. (Publ. No.26).

Lu, J. J. and Zhang, J. X. 1996 Feeding ecology of three wintering geese species at lower Yangtze valley, China. Pp. $143-152$ in China ornithological research. Beijing, China: China Forestry Publishing House.

Madsen, J., Cracknell, G. and Fox, A. D., eds. (1999) Goose populations of the Western Palearctic. A review of status and distribution. Wageningen, The Netherlands: Wetlands International. (Wetlands International Publ. No. 48).

Meng, F. J., Fox, A. D., Liu, J., Yang, W., Shan, K. Q. and Cao, L. (In prep.) Effects of length of growing season on investment in tuber biomass and sexual reproduction by Vallisneria spinulosa S.Z. Yan ramets.

Meng, H. X. (2010) Wintering waterbird survey at the Anhui Shengjin Lake National Nature Reserve, China 2009/2010. BSc Thesis. Hefei, China: University of Science and Technology of China (in Chinese).

NWCAPC (2000) National wetland conservation action plan for China. Beijing, China: State Forestry Administration.

Owen, M. (1972) Some factors affecting food intake and selection in White-fronted Geese. J. Anim. Ecol. 41: 79-92.

Shankman, D. and Liang, Q. (2003) Landscape changes and increasing flood frequency in China's Poyang Lake region. Prof. Geogr. 55: 434-445.

Shimada, T. (2002) Daily activity pattern and habitat use of Greater White-fronted Geese 
wintering in Japan: factors of the population increase. Waterbirds 25: 371-377.

Syroechkovskiy, Jr. E. E. (2006) Long-term declines in Arctic goose populations in eastern Asia, Pp. 649-662 in G. C. Boere, C. A. Galbraith and D. A. Stroud, eds. Waterbirds around the world. Edinburgh, UK: The Stationery Office.

Wang, Z. Y., Lee, J. H. W. and Cheng, D. S. (2005) Impacts of the TGP project on the Yangtze River ecology and management strategies. Internatn. J. River Basin Manage. 3: 237-246.

Waterbird Specialist Group of Chinese Ornithological Association (1994) Waterbird research in China. Shanghai, China: East China Normal University Press.

$\mathrm{Xu}, \mathrm{K} .$, Milliman, J. D., Yang, Z. and Wang, H. (2006) Yangtze sediment decline partly from Three Gorges Dam. EOS, Trans. Am. Geophys. Union 87: 185-196.

Yang, S. L., Zhang, J. and Xu, X. J. (2007) Influence of the Three Gorges Dam on downstream delivery of sediment and its environmental implications, Yangtze River. Geophys. Res. Lett. 34: L10401, DOI: 10.1029/2007GLo29472.

Yang, Z., Wang, H., Saito, Y., Milliman, J. D., $\mathrm{Xu}$, K., Qiao, S. and Shi, G. (2006) Dam impacts on the Changjiang (Yangtze) River sediment discharge to the sea: The past 55 years and after the Three Gorges Dam. Water Resources Res. 42: Wo4407, DOI:10.1029/2005WRo03970.

Ydenberg, R. C. and Prins, H. H. T. (1981) Spring grazing and the manipulation of food quality by Barnacle Geese. J. Appl. Ecol. 18: 443-453.

Zhang, J. and Lu, J. (1999) Feeding ecology of two wintering geese species at Poyang Lake, China. J. Freshwater Ecol. 14: 439-445.

Zhang, Y., Cao, L., Barter, M., Fox, A. D., Zhao, M. J., Meng, F. J., Jiang, Y. and Zhu, W. Z. (2011) Changing distribution and abundance of swan geese in the Yangtze River floodplain: the likely loss of a very important site. Bird Conserv. Int. 21: $36-48$.

\section{MEIJUAN ZHAO, PEIHAO CONG, MARK BARTER, LEI CAO*}

School of Life Science, University of Science and Technology of China, Hefei, Anhui 230026, PR China.

\section{ANTHONY D. FOX}

Department of Bioscience, Aarhus University, Kalø, Grenåvej 14, DK-8410 Rønde, Denmark.

${ }^{*}$ Author for correspondence; email: caolei@ustc.edu.cn

Received 27 May 2011; revision accepted 12 October 2011; Published online 6 February 2012 